\title{
Hypoglossal-vertebral entrapment syndrome
}

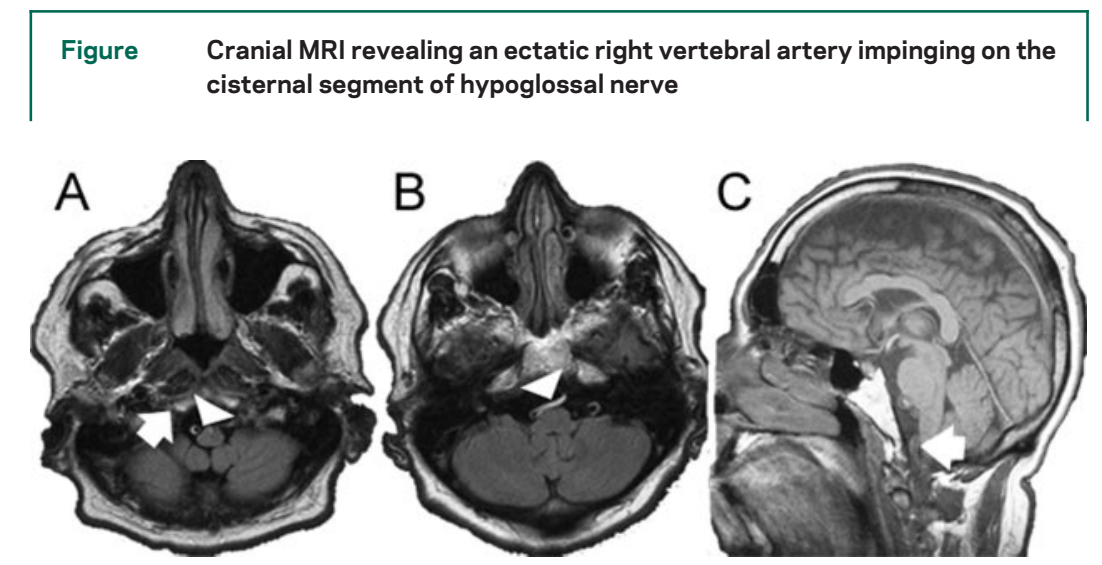

A 54-year-old man presented with nonprogressive dysarthria due to isolated right hypoglossal nerve (HN) palsy. The cranial MRI reveals an ectatic right vertebral artery impinging on the cisternal segment of $\mathrm{HN}$ (figure).

The hypoglossal-vertebral entrapment syndrome ${ }^{1}$ occurs as the hypoglossal rootlets converge directly over the distorted vessel with resultant mechanical compression and direct nerve ischemia. Indeed, HN partly derives its blood supply from vertebral branches. ${ }^{2}$

Intracranial dolichoectasia is another media-involving arteriopathy with association to small vessel diseases. Validated surgical or endovascular interventions do not exist for this condition. Treatment should address identifiable vascular risk factors along with symptomatic speech rehabilitation.

Yasser Aladdin, MD, Zaeem A. Siddiqi, MD, PhD, Khurshid Khan, MD, FRCPC, S. Nizam Ahmed, MD, FRCPC, Edmonton, Alberta, Canada

Disclosure: The authors report no disclosures.

Address correspondence and reprint requests to Dr. S. Nizam Ahmed, Division of Neurology, University of Alberta Hospital, 2 E3 Walter McKenzie Center, 8440-112 St., Edmonton, Alberta, Canada T6G 2B7; snahmed@ualberta.ca

1. Rollnik JD, Sindern E, Mosler F, Spring B, Malin JP. Isolated peripheral hypoglossal palsy caused by a kinking of the left vertebral artery (hypoglossal vertebral entrapment syndrome). Eur Neurol 1996;36:324-325.

2. Gibo H, Marinkovic S, Nikodijevic I, Stimec B, Erden A. The blood supply of the hypoglossal nerve: the microsurgical anatomy of its cisternal segment. Surg Neurol 1997;48:85-91. 


\title{
Neurology
}

\author{
Hypoglossal-vertebral entrapment syndrome \\ Yasser Aladdin, Zaeem A. Siddiqi, Khurshid Khan, et al. \\ Neurology 2008;71;461 \\ DOI 10.1212/01.wnl.0000324424.70503.69
}

\section{This information is current as of August 4, 2008}

\section{Updated Information \& Services}

References

Subspecialty Collections

Permissions \& Licensing

\section{Reprints}

including high resolution figures, can be found at: http://n.neurology.org/content/71/6/461.full

This article cites 2 articles, 0 of which you can access for free at: http://n.neurology.org/content/71/6/461.full\#ref-list-1

This article, along with others on similar topics, appears in the following collection(s):

All Clinical Neurology

http://n.neurology.org/cgi/collection/all_clinical_neurology Arteriovenous malformation

http://n.neurology.org/cgi/collection/arteriovenous_malformation MRI

http://n.neurology.org/cgi/collection/mri

Information about reproducing this article in parts (figures,tables) or in its entirety can be found online at:

http://www.neurology.org/about/about_the_journal\#permissions

Information about ordering reprints can be found online:

http://n.neurology.org/subscribers/advertise

Neurology ${ }^{\circledR}$ is the official journal of the American Academy of Neurology. Published continuously since 1951, it is now a weekly with 48 issues per year. Copyright . All rights reserved. Print ISSN: 0028-3878. Online ISSN: 1526-632X.

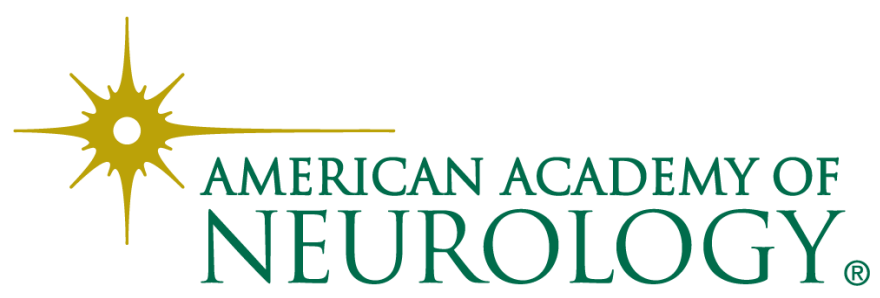

